\title{
The impact of open access on intra- and inter-modal rail competition. A national level analysis in Italy.
}

\author{
Angela S. Bergantino* $^{*} \quad$ Claudia Capozza ${ }^{\dagger} \quad$ Mauro Capurso $^{\ddagger}$
}

\begin{abstract}
During 2012 the Italian passenger market has experienced the entry of a new operator, Nuovo Trasporto Viaggiatori (NTV) on the high speed rail (HSR) market segment, in competition with the incumbent Trenitalia. The Italian market is the first and most extensive case in Europe where two railway companies compete for HSR services on open access basis. In this paper we empirically explore the competitive effects of the newcomer's entry in the passenger market tackling two issues. First, we study price and capacity effects of the stemming intra-modal competition. Second, we measure the impact of inter-modal competition by HSR on airline pricing behaviour. The results show that the two railway companies engage in strategic pricing, although to a different degree on different routes and that capacity and frequency are strategic variables. We also find that airlines significantly reduce fares when flights are in direct competition with HSR services.
\end{abstract}

Key words: intra-modal competition, inter-modal competition, airline pricing, railway pricing. JEL Codes: L11; L92; L93

\footnotetext{
*University of Bari Aldo Moro (Italy). Email: angelastefania.bergantino@uniba.it.

† University of Bari Aldo Moro (Italy). Email: claudia.capozza@uniba.it.

$¥$ University of Bari Aldo Moro (Italy) and University of Leeds (UK). Email: mauro.capurso@uniba.it.
} 


\section{Introduction}

In recent decades the competition between rail and air transport in the short- and medium-haul passenger market has steadily increased. Before the introduction of high-speed rail (HSR) services in the second half of the $20^{\text {th }}$ century, rail transport did not compete with air transport, given the huge difference in travelling time. The provision of HSR services notably reduced the gap in the city-centre to city-centre travelling time. The Union Internationale des Chemins de fer (2010) classifies HSR services as those lines running at a minimum of $250 \mathrm{~km} / \mathrm{h}$ (155mph). Actually, González-Savignat (2004) argues that HSR services can even be seen as a new form of railway transport.

By improving the quality of services over the conventional ones, HSR transport generates a significant competitive pressure on airline companies over specific travelling distances. According to the Union Internationale des Chemins de fer (2010) the "HSR services being less rapid than air still can hold the majority of market shares when the travelling time ranges between $2 \mathrm{~h}$ and $3 \mathrm{~h} 30 . "$ In many European countries there is evidence of a significant substitution effect between HSR and airline services. ${ }^{1}$ In twenty years, the demand for HSR services increased sevenfold, from 15.23 thousand million pax/km in 1990 , to 110.35 thousand million pax $/ \mathrm{km}$ in 2011 . Likewise, the share of HSR services has increased from $15.9 \%$ in 1991 , to $27.1 \%$ in 2011 , more than one percentage point per year. ${ }^{2,3}$. The supply of a new quality service has led not only to an increase in the demand for rail transport but also to traffic reallocation. ${ }^{4}$

\footnotetext{
${ }^{1}$ The Paris-Brussels line is about $320 \mathrm{~km}$ long, corresponding to $1 \mathrm{~h} 15$ of travelling time. After the introduction of HSR transport, there has been a reallocation of traffic. The demand changed from $25 \%$ to $50 \%$ for rail services, from $61 \%$ to $43 \%$ for car services and from $7 \%$ to $2 \%$ for air services. The impact has been even more relevant on the Madrid-Seville line, almost $500 \mathrm{~km}$ long, corresponding to $2 \mathrm{~h} 15$ of travelling time. Before the introduction of HSR services, trains held about one third of total demand. Thereafter, trains account for over $84 \%$ of the demand (Union Internationale des Chemins de fer, 2010).

${ }^{2}$ Statistical pocketbook 2013, Directorate-General for Mobility and Transport.

${ }^{3}$ An ample body of literature explains the effects on transport demand by the introduction of new services. See, among others, Gutiérrez et al. (1996), Gutiérrez (2001), Willigers and van Wee (2011) and Cao et al. (2013).

${ }^{4}$ If we look at the rail sector as a whole (including conventional services), the increase in demand from 1990 to 2011 was rather small (from 400.7 to 407.1 thousand million pax $/ \mathrm{km}$ ). In the 1990 s there was a sharp demand fall. If we consider only the period 2000-2011, we actually see a more significant increase in demand, equal to $9.8 \%$ (from 370.7 to 407.1 thousand million $\mathrm{pax} / \mathrm{km})$.
} 
The arrival of HSR services has mainly stimulated the research on the inter-modal competition effects. However, the liberalisation of the rail market has attracted new operators and has fostered the intra-modal (on-track) competition that deserves to be studied.

In this work, we explore the Italian passenger market, a suitable case for analysing the impact of HSR on the transport sector. Indeed, it is the first and most extensive case in Europe ${ }^{5}$ where two railway companies compete on an open access basis for HSR services on the domestic market, ${ }^{6}$ allowing us to study two complementary issues.

First, we explore price and capacity effects of intra-modal competition among HSR companies. Basically, we verify whether there is a strategic interaction in fare and capacity decisions between Trenitalia and NTV on all the competing routes. The market penetration of Nuovo Trasporto Viaggiatori (NTV) has been very fast. In April 2012, NTV started the HSR services on the RomeMilan line in competition with the incumbent Trenitalia. Since then, NTV entered other city-pair markets, namely the Rome-Venice and the Rome-Turin routes and after that, the Salerno-NapoliRome and the Milano-Ancona routes. In 2012, NTV moved more than 2 million passengers, against the 25 million of Trenitalia (Longobardi, 2013 and Trenitalia, 2012) while, in 2013, NTV conquered $25 \%$ of the market share, moving about 7 million passengers (Nuovo Trasporto Viaggiatori, 2013).

Second, we measure the effect of inter-modal competition on airline pricing behaviour and focus on the Rome-Milan market. On this line, HSR transport is a substitute for air transport as the total journey time is below three hours, and we can observe intra- and inter- modal competition thanks to the open access regulation. Indeed, $N T V$ entry has fostered competition with the former incumbent Trenitalia but also with the airlines. HSR services started to be supplied in 2008 on the Rome-Milan

\footnotetext{
${ }^{5}$ This was shown in Bergantino (2015), providing a comparison across European countries on the process of opening up to competition in the railway market.

${ }^{6}$ There are a few cases of open access competition throughout Europe. On the international route linking Brussels and Koln, the French, the Belgium and Dutch railway companies - allied in the consortium Thalys - compete with the German incumbent Deutsche Bahn. On conventional services, the domestic open access competition appeared in Germany (on the Hamburg-Koln route), Austria (on the Vienna-Litz route), Czech Republic (on the Praga-Ostrava route) and in the UK (on some parts of the railway line connecting London to Scotland). However, there is a debate on whether the competing services that operate on the East Coast Main Line should be considered HSR or conventional.
} 
line. The rail market share was $36 \%$ whilst the airline market share was $51 \%{ }^{7}$ In 2012 , with the entry of NTV and the reaction of Trenitalia, the rail market share reached $68 \%$, whilst the airline market share decreased to 26\% (Ministero delle Infrastrutture e dei Trasporti (MIT), 2013 and Nuovo Trasporto Viaggiatori, 2013).

The Autorità Garante per la Concorrenza ed il Mercato (2013) notes that when Trenitalia started the non-stop service between Rome and Milan, the number of rail passengers increased along with the average revenue per passenger. The revenue increment could be due to the substitution of Intercity and Eurostar trains with HSR services, usually more expensive. At the same time, Alitalia experienced a small drop in the number of passengers and a reduction in the average revenue per passenger. The AGCM estimates a range of daily passengers from 3,000 - 6,000 in 2009. The estimated range reduces to $2,000-4,000$ (10 to $20 \%$ ) in 2011 . The number of passengers using HSR non-stop Trenitalia services increased from 3,000 - 6,000 in December 2009, to 5,000 10,000 in December 2010 (10 to $30 \%$ ). The increment is also due to the elimination of a large number of conventional services (e.g. Intercity).

Besides diverting a substantial share of passengers from air transport to rail transport, ${ }^{8}$ the intermodal competition might exert a significant downward pressure on airfares. Past empirical studies on competition in the transport sector analyse the effect of airline competition on fares ${ }^{9}$ with regard to the role of low cost carriers (LCCs). ${ }^{10} \mathrm{~A}$ number of studies explore the air-rail competition to analyse the actual or the potential modal shift between air and rail due to the entry of HSR operators.

The database we use to carry out the empirical analyses is unique. Data on one-way fares are retrieved from railways' and airlines' websites by simulating reservations. Fares are recorded every day starting at sixty booking days before departure. The intra-modal competition analysis applies to

\footnotetext{
${ }^{7}$ The road transport held $13 \%$ of the market share.

${ }^{8}$ According to NTV (2013), more than 2 million passengers on the Rome-Milan route only, were diverted from airlines between 2009 and 2012.

${ }^{9}$ See, among the others, Gaggero and Piga (2010, 2011) and Bergantino and Capozza (2015).

${ }^{10}$ Consumers benefit from the increased supply of services on point-to-point connections, but also from fares' reduction due to the competitive pressures exerted by LCCs on legacy carriers (see, for instance, Bergantino, 2006; Bergantino and Ponti, 2006; Fageda et al. 2011).
} 
all the Italian domestic routes on which Trenitalia and NTV compete, whereas the inter-modal competition analysis focuses on the Rome-Milan line because air and rail travelling times are very similar and, thus, the transport modes can be considered substitutes.

The results show that the on-track competition leads to an overall increase in the supply of services and, thus, to a greater utilization of the network. The arrival of NTV has not induced Trenitalia to cut down its supply. The analysis of the daily frequencies highlights that Trenitalia has increased the capacity by more than $30 \%$ from the year previous to NTV entry, and the overall capacity on the Rome-Milan line has increased by $56 \%$. Moreover, the railway companies are found to engage in strategic pricing, although to a different degree on different routes. The incumbent's tariffs are $29.92 \%$ to $34.67 \%$ higher than the newcomer's, thus there is no evidence of predatory or aggressive pricing behaviour by Trenitalia.

Our results have relevant implications for antitrust policy as $N T V$ reported to the Italian Competition Authority (Autorità Garante della Concorrenza e del Mercato, AGCM) a number of cases of alleged discriminatory behaviour by: Trenitalia, the infrastructure manager Rete Ferroviaria Italiana (RFI) and the mother company Ferrovie dello Stato Italiane SpA (FSI). ${ }^{11}$ On May 28, 2013, the AGCM started an investigation into Trenitalia's pricing strategies on the Rome Termini-Milan Centrale route, as $N T V$ accused the incumbent of dumping and cross subsidization. NTV's claim is that Trenitalia sets fares for HSR services that do not cover the operating costs, and compensates the losses with the subsidies received from the regions and the local authorities under the public service obligations (PSO) contracts. On March 12, 2014, the AGCM closed the investigation for abuse of dominant position declaring FSI to be not guilty, although it was required to guarantee a fairer behaviour towards competitors.

\footnotetext{
${ }^{11}$ The liberalization process was not so straightforward. In March 2011, NTV complained that RFI was hindering its entry by making last-minute changes to the network statements. The holding FSI and some of its controlled companies were also accused of abuse of their dominant position, with reference to the slots' concession to NTV on the RomeMilan line. Trenitalia, in turn, when NTV received the authorization to operate, accused the newcomer of creamskimming and cherry picking (for a review of the cream-skimming practices in the railway industry, see Alderighi and Bergantino, 2011, 2013).
} 
Finally, the empirical analysis on the inter-modal competition shows a positive spillover effect for consumer welfare. The air-rail competition induces airlines to decrease fares. In fact, airlines are found to reduce fares up to 13.26 Euros when they compete with HSR operators. This can be seen as an indirect benefit of the HSR transport that should be considered in the cost-benefit analysis by policymakers in the evaluation of HSR infrastructure investments.

The paper is organized as follows. In Section 2 we survey the literature. In Section 3 we analyse the liberalisation process in the European Union, with a focus on the appearance of intra-modal competition in the Italian rail sector. In Section 4 we describe the data and the collection procedure. In Section 5 we illustrate the analysis of the intra-modal competition and, then, we show the results. In Section 6 we carry out the empirical analysis on the inter-modal competition. Finally, in Section 7 we draw some conclusions and policy implications.

\section{Literature review}

This paper builds upon the stream of literature on the inter-modal competition analysis. The first study is Janic (1993) who claims that HSR transport competes with air transport over a relatively large range of distances, between 400 and 2,000 km. A number of papers use the stated preference (SP) approach to explore the possible substitution between the two transport modes. GonzálezSavignat (2004) points out, on the Madrid-Barcelona line, the high substitutability between air and HSR transport. Actually, the HSR market share is expected to reach $60 \%$ in the leisure segment and $40 \%$ in the business segment. Roman et al. $(2007,2010)$ show that travellers' willingness to pay for transport services on the corridors Madrid-Zaragoza and Madrid-Barcelona seems to be higher for HSR services than for air transport services. Further, Martin and Nombela (2007) predict, on Spanish domestic lines, that the infrastructure that upgrades to accommodate HSR services might lead to a significant modal shift so that HSR transport would get $22.8 \%$ of the market share. This percentage may triple over the next decade. More recently, for the London-Paris market, Behrens 
and Pels (2012) estimate the degree of the inter-modal competition using elasticity measures of market share. The results show that HSR is an effective competitor for both Full Service Carriers (FSCs) and Low Cost Carriers (LCCs). However, FSCs can be pushed out of the market when they encounter fierce competition from HSR. Finally, Betancor and Jiménez (2012) study the reaction of airline companies to the introduction of HSR services in Spain. The provision of HSR services reduces the number of air operations by $17 \%$, although the flag carrier Iberia does not seem to be affected by HSR competition.

Other contributions explore the competitive dynamics between railway and airline companies. Antes et al. (2004) study the entry of LCCs in the German passenger market, finding that air and rail companies are induced to redesign their pricing strategy as long as the competitive pressure of LCCs increases. Ivaldi and Vibes (2005) adopt a game theoretical framework to explore the intraand inter-modal competition on the Cologne-Berlin connection, where the flag carrier Lufthansa competes with the rail company Deutsche Bahn AG and three LCCs (DBA, Germanwings and Hapag-Lloyd Express). They provide evidence that a small number of competitors is enough to create a high degree of intra- and inter-modal competition. The study by Steer Davies Gleave (2006) shows that airlines fares can fall below the level of fares charged for HSR services when the HSR transport holds a relatively large market share. Since the journey time is the most important determinant of travellers' demand, the HSR operator can even increase prices without losing a significant market share. Even Dobruszkes (2011), analysing five European city-pairs (Paris-Metz, Paris-Brussels, Brussels-London, Paris-Marseilles, and Cologne-Munich), highlights the importance of the travelling time in order for HSR to successfully compete with airplanes. ${ }^{12}$ Consistent with this, Yang and Zhang (2012) theoretically prove that airline fares decrease as rail speed increases when the marginal cost of HSR is not too large and as the airport access time increases. They also show that, on the contrary, increases in airport access time leads to rail fare increases.

\footnotetext{
${ }^{12}$ Other factors such as frequencies, fares and geographical structure, play a role, as they influence the waiting time or the access time to the transport service.
} 
Campos and de Rus (2009) provide different worldwide examples on the effectiveness of intermodal competition. Among others, the case of the Korean passenger markets is noteworthy, where, in two years from their appearance in 2004, HSR services have overcome the air transport. Further, on the London-Paris route, HSR services have been able to steal passengers from competing modes and to attract new travellers, reaching, overall, $70 \%$ of the market share.

Differently from the aforementioned papers, Givoni and Banister (2006) consider the potential for cooperation rather than competition between HSR and air transport. They show that airlines can use rail services as an additional spoke in their network, when economically convenient. Actually, Air France reduced its services on the Paris-Brussels line, following the agreement with the HSR operator Thalys that, in return, reserved one to two carriages for moving passengers from Brussels to the rail station of the Paris Charles De Gaulle Airport, the hub of Air France (see Dobruszkes, 2011). Behrens and Pels (2012) predict that British Airways and Air France would provide a more attractive service to passengers by integrating HSR services in their networks instead of competing. Preston (2012) evaluates the pros and cons of HSR investments in Great Britain and points out that cooperation among transport modes depends on the provision of an HSR line to the London Heathrow Airport and would also depend upon whether rail and airline companies are willing to sign an agreement for the inter-modal integration. Kappers and Merkert (2013) interview airline managers asking, among other questions, which are the factors they perceived as entry barriers to the airline market. Most of the managers claim that the presence of an HSR service competing on the same air route represents an effective entry barrier. Further, the cooperation with the rail company providing connections to airlines' hub airports is deemed as a considerable entry barrier by a third airline. Dobruszkes and Givoni (2013) point out that substitution or complementarity between HSR and air transport depends on routes and airports' features and other local conditions. Dealing with environmental issues, they consider HSR transport as a strategic resource, even from the air transport perspective, as it better covers the medium-haul market segment. Finally, Bergantino and Capozza (2014) show that airline companies change fares in two different ways 
depending on the degree of inter-modal competition, based on the infrastructure endowment. First, airlines charge higher fares in a more concentrated market structure when the inter-modal competition is limited. Second, airlines address an inter-temporal price discrimination (IPD) strategy seeking to segment, to a greater extent, the passenger market when the inter-modal competition is effective.

\section{The liberalization process from the European Union to Italy: the appearance of intra- modal competition in the HSR sector}

In the last twenty years, the European Commission (EC) has been very active in restructuring the rail transport market and in strengthening the position of railways with respect to other transport modes. The opening-up of the national freight and passenger markets to cross-border competition has been a major step towards the creation of the integrated European railway area that breaks down barriers in favour of a more competitive rail sector, with better connections between the European Union and the neighbouring markets. ${ }^{13}$

Starting from 1991 with the Directive 91/440/EEC, ${ }^{14}$ a series of directives, regulations and other legislative initiatives have been issued and implemented in order to develop the liberalization and market-opening process. The three railway packages, introduced respectively in 2001, 2004 and 2007, have gradually led to complete open access for commercial freight and international passenger operators. The $1^{\text {st }}$ and the $2^{\text {nd }}$ railway packages deal with the liberalisation of the freight

\footnotetext{
${ }^{13}$ Holvad et al. (2013) provide an overview from the economic perspectives of the European Union railway reform initiatives. Further, a review on the beginning of the liberalisation process in Italy can be found in Ponti and Erba (2002) and in Ponti and Beria (2009).

${ }^{14}$ The 91/440/EEC can be considered as the Magna Carta for the liberalisation of the railway sector in Europe. It states that there should be a distinction between infrastructure managers, who run the network, and the railway companies that use it for moving passengers or goods. The rationale is the separation of the essential functions - such as the allocation of rights or rail capacity (train paths), infrastructure charging and licensing - from the transport services' operations. Moreover, it prescribes that public funds granted for the realisation of the essential infrastructure for the supply of PSO or for the supply of transport services under PSO (the so-called "compensation funds"), could not be used to finance transport operations in the unregulated market. This is meant to avoid distortions of competition and to grant new rail operators fair access to the market.
} 
market by providing more comprehensive access rights and required the opening of the market for international rail freight services to be accomplished by January $1,2006{ }^{15}$

The $3^{\text {rd }}$ railway package concerns the passenger market. In the official documents, the right to pick up passengers at any station located on an international route and take them to any other, including stations located in the same member state, is granted to railway operators, thereby providing for cabotage in any member states (Holvad et al., 2013). Some member states went a step further. Italy, for instance, opened up competition in the high-speed domestic market to any licensed operator.

Recently, the EC has proposed a $4^{\text {th }}$ railway package with the purpose of further boosting the market opening to domestic passenger services and enhancing the independence of infrastructure managers from railway operators. Before being adopted, the last package needs to be approved by the European Parliament and member state governments.

This regulatory framework leads to different sub-models of railway organisation within member states (Holvad and Godward, 2013): ${ }^{16}$

- complete separation or Swedish model, with fully separated railway undertakings and infrastructure managers;

- separation of key powers or French model, with fully separated railway undertakings and infrastructure managers, influenced but not controlled by the former incumbent railway undertaking; and

- holding company or German model, with "Chinese walls" between the incumbent railway undertaking and the infrastructure manager, coexisting in the same group;

- private ownership or British model, with fully privatised services and networks. While the previously listed models are applied to a different extent also in other EU countries (i.e. the

\footnotetext{
${ }^{15}$ The final date for completing the opening of all rail freight services, including cabotage, was January 1, 2007.

${ }^{16}$ The Irish railway system has been allowed to keep a strict integration between the incumbent railway undertaking and the infrastructure manager, as it is not connected with any other European network. For this reason, the Irish model is not relevant to our discussion. For a review on railway organisation models see Merkert (2012) and Holvad and Godward (2013).
} 
German model is the prevailing one in Italy), besides that of origin, no other EU member state has adopted a "private model" yet.

In Italy, the liberalization process started with the adoption of the Directive 91/440/EEC (implemented by the Presidential decree 277/98) and the adoption of the Directives 95/18 and 95/99 (implemented by the Presidential decree 146/99). Decrees 188/03 and 15/10 further define the framework. Both of these decrees liberalised the access to the railway infrastructure and the supply of railway services for freight and passenger segments. Italy applies the German model. On June 1, 2000, the two main divisions of the Italian railway company, infrastructure and service, were separated. Currently RFI manages the rail tracks and the infrastructure, while Trenitalia ${ }^{17}$ manages the train and passenger sections. Both are FSI subsidiaries and entirely publicly owned.

Since April 2012, following the opening to competition, NTV, an Italian private company, ${ }^{18}$ the first open access operator in Europe, has also provided HSR services, with high speed trains running at $300 \mathrm{~km} / \mathrm{h}(190 \mathrm{mph})$.

Trenitalia and NTV compete, mostly, on three routes:

- Rome-Milan, since April 2012;

- Rome-Turin, since October 2012; and

- $\quad$ Rome-Venice, since December 2012.

These routes are connected to southern Italy with Salerno and Naples. Since December 2013, NTV has run operations on the Adriatic corridor, linking Ancona to Milan and Turin. NTV competes with Trenitalia on these routes as well.

In July 2013, the set up of the National Authority for Transport represented an important step towards the creation of an independent regulatory body. The Authority is in charge of regulating access to the infrastructure and related services, on the basis of fair and non-discriminatory conditions, by defining the criteria for the access charges and by analysing the efficiency of the

\footnotetext{
${ }^{17}$ Trenitalia is the primary rail operator in Italy, managing more than 9,000 trains per day and moving more than half a billion passengers and 80 million tons of goods every year.

${ }^{18}$ NTV is party publicly owned by the French State Railway Company (SNCF) and controlled by SNCF Voyages Développement S.a.S that hold a share of $20 \%$.
} 
separation between the infrastructure manager and the train-operating companies. Indeed, the first intervention on March 6, 2014, opened the procedure for the adoption of regulatory measures to ensure the conditions for fair and non-discriminatory access to the rail infrastructure, with the aim of encouraging competition, production and cost efficiency. ${ }^{19}$ However, it is too early to say how the Authority will affect the market.

\section{Data collection}

The dataset we use to carry out the empirical analyses on the on-track competition and the air-rail competition is unique. Starting at sixty booking days before departure, we simulate every day the purchase of rail and air tickets from each company's website and we record the one-way fares. We always choose the lowest fares among those offered for different travel classes in the same time slot. Further, data on the number of rail daily services and airline daily flights are taken from official companies' timetables.

The analysis on intra-modal on-track competition concerns the following routes:

- Rome Termini - Milan Centrale and return, served by Trenitalia;

- Rome Tiburtina - Milan Porta Garibaldi and return, served by NTV;

- Rome Termini - Turin Porta Nuova and return, served by Trenitalia;

- Rome Tiburtina - Turin Porta Susa and return, served by NTV;

- Rome Termini - Venice Santa Lucia and return, served by Trenitalia; and

- Rome Tiburtina - Venice Santa Lucia and return, served by NTV.

The analysis on inter-modal competition among HSR operators and airline companies focuses on the Rome-Milan line. On this route the travelling times of the two transport modes are comparable, thus they can be considered substitutes. Moreover, the market dimension supports the focus on

\footnotetext{
${ }^{19}$ Autorità Nazionale per i Trasporti (2014).
} 
Rome and Milan, the largest cities in Italy, and among the major agglomerates in Europe. ${ }^{20}$ The competing air routes are:

- Rome Fiumicino (FCO) - Milan Linate (LIN) and return; and

- Rome Fiumicino (FCO) - Milan Malpensa (MXP) and return.

Airlines flying on those connections are Alitalia and EasyJet. The dataset is comprised of 9,089 observations on the Rome Fiumicino (FCO) - Milan Linate (LIN) route and return, and 1,098 observations on the Rome Fiumicino (FCO) - Milan Malpensa (MXP) route and return. Data are collected for some departure dates in February on four different time slots covering the whole day $(05.00-08.30 ; 13.00-15.00 ; 17.00-19.00 ; 19.00-21.00) .{ }^{21}$ Table 1 summarises the main features of the routes.

Table 1. Characteristics of the routes.

\begin{tabular}{|c|c|c|c|c|}
\hline \multicolumn{2}{|l|}{ Route } & Carrier & $\begin{array}{l}\text { Avg travel I } \\
\text { time (min) }\end{array}$ & $\begin{array}{c}\text { Distance } \\
(\mathbf{K m})\end{array}$ \\
\hline Rome Fiumicino & - Milan Linate & Alitalia/EasyJet & 70 & 470 \\
\hline Rome Fiumicino & - Milan Malpensa & AlitalialEasyJet & 75 & 511 \\
\hline Rome Termini & - Milan Centrale & Trenitalia & 187 & 567 \\
\hline Rome Tiburtina & - Milan Porta Garibaldi & $N T V$ & 195 & 578 \\
\hline Rome Fiumicino & - Venice Marco Polo & Alitalia/EasyJet & 75 & 412 \\
\hline Rome Termini & - Venice Santa Lucia & Trenitalia & 220 & 528 \\
\hline Rome Tiburtina & - Venice Santa Lucia & $N T V$ & 215 & 524 \\
\hline Rome Fiumicino & - Turin Caselle & Alitalia/Blu-Express/Meridiana & 85 & 529 \\
\hline Rome Termini & - Turin Porta Nuova & Trenitalia & 260 & 716 \\
\hline Rome Tiburtina & - Turin Porta Susa & $N T V$ & 255 & 706 \\
\hline
\end{tabular}

Source: Authors' elaboration.

\footnotetext{
${ }^{20}$ The Rome-Milan line is one of the most important in Europe, having more than 5,300,000 passengers travelling by airplane (Eurostat, 2011). Thousands of people travel every day for many reasons between the two main Italian cities. Rome is the Italian political capital, whilst Milan is the economic and financial heart of the country. Rome, with 2.8 million residents in $1,285.3 \mathrm{~km}^{2}$, is the largest and most populated city in Italy and fifth in the EU considering the population within city limits. The urban area of Milan is the fifth largest in the EU, with an estimated population of about 5.2 million. The city of Rome produces $6.7 \%$ of the national GDP, more than any other city in Italy. The whole province of Milan generates approximately 9\% of the national GDP (estimated in €132 billion in 2010) and the Lombardy region generates approximately $20 \%$ of the GDP (estimated in $€ 325$ billion in 2010). For these reasons, the Rome-Milan line is a very important link, not only for the Italian economy but also for the entire EU economy.

${ }^{21}$ In order to allow for credible time schedules, the time slots used diverged slightly on the routes that originated in Rome from the ones that originated in Milan, Turin and Venice.
} 


\section{The analysis of intra-modal (on-track) competition}

The analysis of on-track competition focuses on the three main HSR routes that connect Rome to northern Italy. We analyse the rail operators' behaviour with respect to capacity and pricing decisions. To the best of our knowledge, this is the first paper that studies railway companies' behaviour when they compete on an open access basis. Actually, the Italian case is the only one in Europe where a private railway company competes against the publicly owned incumbent on HSR lines.

\subsection{Capacity competition}

The Rome-Milan line is one of the railway lines with the highest number of passengers in Europe. In past years, Trenitalia tested different pricing and service quality strategies on this route. In December 2004, Trenitalia started to provide a low cost Eurostar service branded TrenOK. This service was run once a day and was operated by the first generation of tilting Eurostar trains. The journey time was the same as the standard Eurostar but the trains departed and arrived in the secondary stations. TrenOK had only second-class fares that were 37 Euros cheaper than secondclass fares for the standard Eurostar. In November 2005, a new higher quality Eurostar service, named TBiz, targeted to business passengers, was run twice a day for each direction, with a $20 \%$ higher price. In 2008 Trenitalia began the provision of HSR services as they appear today. The HSR are branded FrecciaRossa and run every hour between 6 am and 8 pm. Trenitalia also provides non-stop HRS services every hour between 6 am and $7 \mathrm{pm}$ with a greater frequency during peak times. The supply is also comprised of other services branded FrecciArgento, FrecciaBianca, Intercity and IntercityNight. The travelling time is much higher than the FrecciaRossa, reaching up to 7 h30 with the IntercityNight. Trenitalia carries out rail services from the main stations (Rome Termini and Milan Centrale) and also from the secondary stations (Rome Tiburtina, Milan Porta Garibaldi and Milan Rogoredo). 
In Table 2 we show a picture of the rail services' provision on these lines. From 2009 to 2013, there has been a substantial increase in the supply.

In the last four years, the number of services offered by Trenitalia on the Rome-Milan line has been moderately changed, whilst there has been a substantial improvement in the trains' speed. Between 2009 and 2013, the frequency of HSR services increased by $26.7 \%$ (from 30 to 38 daily services) but the frequency of conventional services dropped by $22 \%$ (from 9 to 7 daily services). It seems that Trenitalia implemented an entry-deterrence strategy to occupy the market as Alitalia did on the same route keeping its slots in use. Actually, the increase in the number HSR services achieved its peak in 2011/2012 (+6 daily services), just before $N T V$ 's entry.

The newcomer NTV provides HSR services only from the secondary stations (Rome Tiburtina, Rome Ostiense, Milan Porta Garibaldi and Milan Rogoredo), with the possibility of purchasing non-stop trains and services with intermediate stops. NTV runs one train per hour during off-peak times and two trains per hour during peak-times.

Overall, the supply on the Rome-Milan line significantly increased by $56.4 \%$ between 2009/2010 to 2013 (from 39 to 61 daily services). In particular, the frequency of HSR services increased by $80 \%$ (from 30 to 54 daily services) in three years. Despite the increase in the supply of Trenitalia, NTV gained a $29.63 \%$ the market share in one year.

Regarding the Rome-Venice and Rome Turin lines, Trenitalia provides services from the main stations (Rome Termini, Venice Santa Lucia and Turin Porta Nuova), whereas NTV provides services from the secondary stations when available (Rome Tiburtina and Turin Porta Susa). Trenitalia also runs conventional services, although it requires up to twice the HSR travelling time.

The supply on the Rome-Turin line also increased in the period considered. The greatest increment of $30.8 \%$ occurred between 2011/2012 and 2013 (from 13 to 17 daily services). On the HSR segment, the increase is even higher, equal to $133 \%$ (from 6 to 14 daily services) in three years.

On the Rome-Venice line, the supply increased by $46.15 \%$ (from 13 to 19 daily services) in three years), while the HSR supply increased by $30.76 \%$ (from 13 to 17 daily services) in three years. 
Table 2. Rail services' provision.

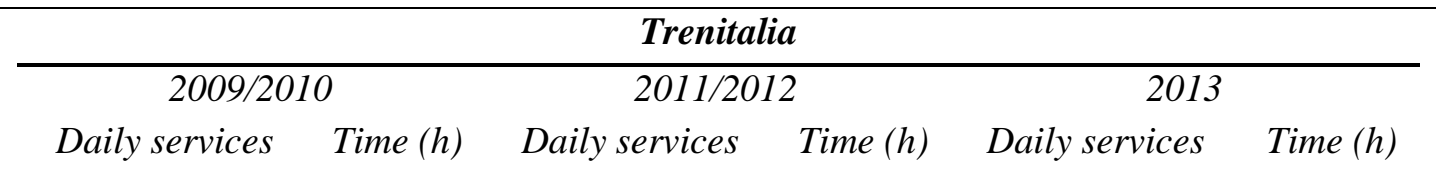

$\frac{\text { NTV }}{2013}$

(n) (n) (n) (n)

\begin{tabular}{|c|c|c|c|c|c|c|c|c|c|}
\hline & & & & & & & & & \\
\hline \multicolumn{10}{|l|}{ 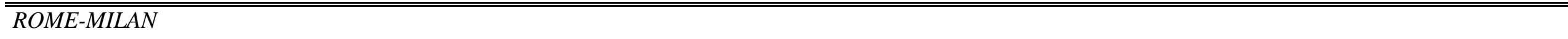 } \\
\hline FrecciaRossa (No Stop) & 16 & 3 & 17 & 3 & 17 & 2.55 & Italo No Stop & 3 & 3.03 \\
\hline FrecciaRossa & 14 & 3.30 & 19 & 3.30 & 21 & 3.20 & Italo & 13 & 3.30 \\
\hline Total HSR & 30 & & 36 & & 38 & & & 26 & \\
\hline FrecciArgento & & & & & 1 & 4.15 & & & \\
\hline FrecciaBianca & 1 & 6.40 & 2 & 6.40 & 1 & 6.40 & & & \\
\hline IntercityNight & & & & & 2 & 7.30 & & & \\
\hline Intercity & 5 & 6.40 & 4 & 6.40 & 3 & 6.40 & & & \\
\hline Espresso & 3 & 7.10 & & 7.10 & & & & & \\
\hline Total & 39 & & 42 & & 45 & & & 16 & \\
\hline \multicolumn{10}{|l|}{ 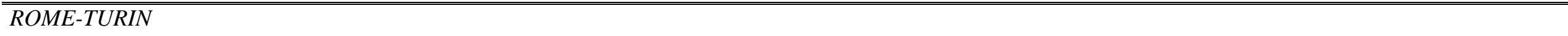 } \\
\hline FrecciaRossa (less stops) & 6 & 4.20 & 10 & 4.20 & 8 & 4.05 & Italo (less stops) & 3 & 4.10 \\
\hline FrecciaRossa & & & & & 6 & 4.30 & Italo & 2 & 4.17 \\
\hline Total HSR & 6 & & 10 & & 14 & & & 5 & \\
\hline FrecciaBianca & & & & & 1 & 6.45 & & & \\
\hline Intercity & 3 & 7.10 & 2 & 7.10 & 1 & 7.15 & & & \\
\hline IntercityNight & & & & & 1 & 10.04 & & & \\
\hline Espresso & 4 & 8.00 & 1 & 8.00 & & & & & \\
\hline Total & 13 & & 13 & & 17 & & & 5 & \\
\hline \multicolumn{10}{|l|}{ (ROME-VENICE } \\
\hline FrecciaArgento & 13 & 3.50 & 18 & 3.50 & 17 & 3.45 & Italo & 5 & 3.35 \\
\hline Total HSR & 13 & & 18 & & 17 & & Italo & 5 & \\
\hline Intercity & & & & & 2 & 6.05 & & & \\
\hline Total & 13 & & 18 & & 19 & & & 5 & \\
\hline
\end{tabular}

Source: Authors' elaboration on operators' timetables 
It is also worth comparing the market share on the routes from Rome to Milan, Venice and Turin (see Figure 1). The market share is defined as the share of the daily services operated by the railway company in a city-pair. ${ }^{25} N T V$ has a slightly greater share on the Rome-Milan. ${ }^{26}$

Figure 1. Market shares on selected HSR lines in Italy.

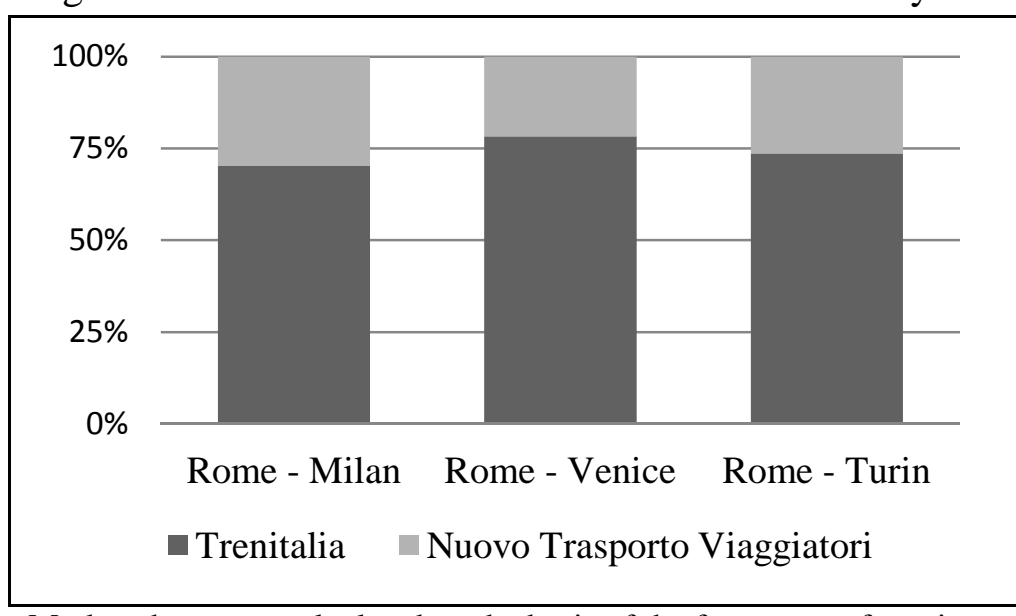

Market shares are calculated on the basis of the frequency of services in a normal working day (2013).

Source: Authors' elaborations on data from operators' websites.

Trenitalia maintains the largest market share, managing more than $70 \%$ of the total services on the selected routes. The trainsets used by the two operators have different capacities (see Table 3), thus we need to assume the same average load factor.

Table 3. Trainsets' capacity.

\begin{tabular}{llccc}
\hline Operator & Brand & Train Class & Route & Number of seats \\
\hline \hline Trenitalia & FrecciaRossa & ETR500 & Rome-Milan & 574 \\
& FrecciaRossa & ETR500 & Rome-Turin & 574 \\
& FrecciArgento & ETR600 & Rome-Venice & 432 \\
\hline NTV & Italo & ETR475 & Rome-Milan & 451 \\
& Italo & ETR475 & Rome-Turin & 451 \\
& Italo & ETR475 & Rome-Venice & 451 \\
\hline
\end{tabular}

Source: www.railfaneurope.net and official operators' websites.

\footnotetext{
${ }^{25}$ In measuring the market shares we should remember that almost all the services have intermediate stops, thus a proportion of seats are used for passengers travelling to intermediate destinations.

${ }^{26}$ Shares are updated to the month of September 2013.
} 
Given the technical characteristics of the trains for HSR services, the capacity of trains can be assumed to be fixed in the short run, as it is extremely difficult to vary the availability of seats in each class according to changes in demand (for example by adding or removing a wagon). It could be possible, however, to modify the menu of tariffs supplied with on-going promotions.

\subsection{Price competition}

Trenitalia and NTV offer 15 and 11 price/quality combinations, respectively, for the rail services. By offering a menu of tariffs with different levels of quality, the rail operators try to induce the passengers with different evaluations to reveal their preferences that can be strategically exploited to avoid a fierce price competition and to extract the greatest part of consumers' surplus.

Basically, passengers can choose between three levels of flexibility (no change - no refund / limited change and refund / unlimited change and refund) and several levels of comfort, although Trenitalia has a more articulate offer for the business users.

In this differentiated-products framework, standing in an oligopoly structure, firms compete in prices and product characteristics. Our focus is on price competition. Actually, product characteristics are fixed in the very short run. We use a two-month time span for the dataset used to conduct the analysis. The characteristics of tickets whose price is observed do not change in the time period of sixty days.

In Table 4 we provide descriptive statistics on Trenitalia and NTV average fares on the selected routes, calculated using data collected from the railways companies' websites (see Section 4).

Table 4. Descriptive statistics.

\begin{tabular}{llcccc}
\hline Connection & Operator & Mean & Std. Dev. & Min & Max \\
\hline \hline \multirow{2}{*}{ Rome-Milan } & Trenitalia & 64.55 & 7.03 & 53.86 & 83.01 \\
& NTV & 50.86 & 7.67 & 45.12 & 79.96 \\
Rome-Venice & Trenitalia & 58.14 & 8.71 & 49.00 & 77.42 \\
& NTV & 44.55 & 7.86 & 38.83 & 75.50 \\
\multirow{2}{*}{ Rome-Turin } & Trenitalia & 66.29 & 11.62 & 53.58 & 90.00 \\
& NTV & 43.31 & 6.01 & 38.00 & 50.00 \\
\hline
\end{tabular}


The average fares posted by Trenitalia are higher than those posted by NTV. Specifically, on the lines Rome-Milan and Rome-Venice lines, Trenitalia applies $29.92 \%$ and $30.50 \%$ higher fares, respectively. The difference is greater for the Rome-Turin line, where Trenitalia set a $34.67 \%$ higher average fare compared to $N T V$.

Besides comparing the average, we also explore the dynamics of fares over time. Figure 2 displays the temporal profile of the average lowest fares collected for Rome-Milan route from the sixty days prior to the departure.

Figure 2. Temporal profile of fares on the Rome-Milan route.

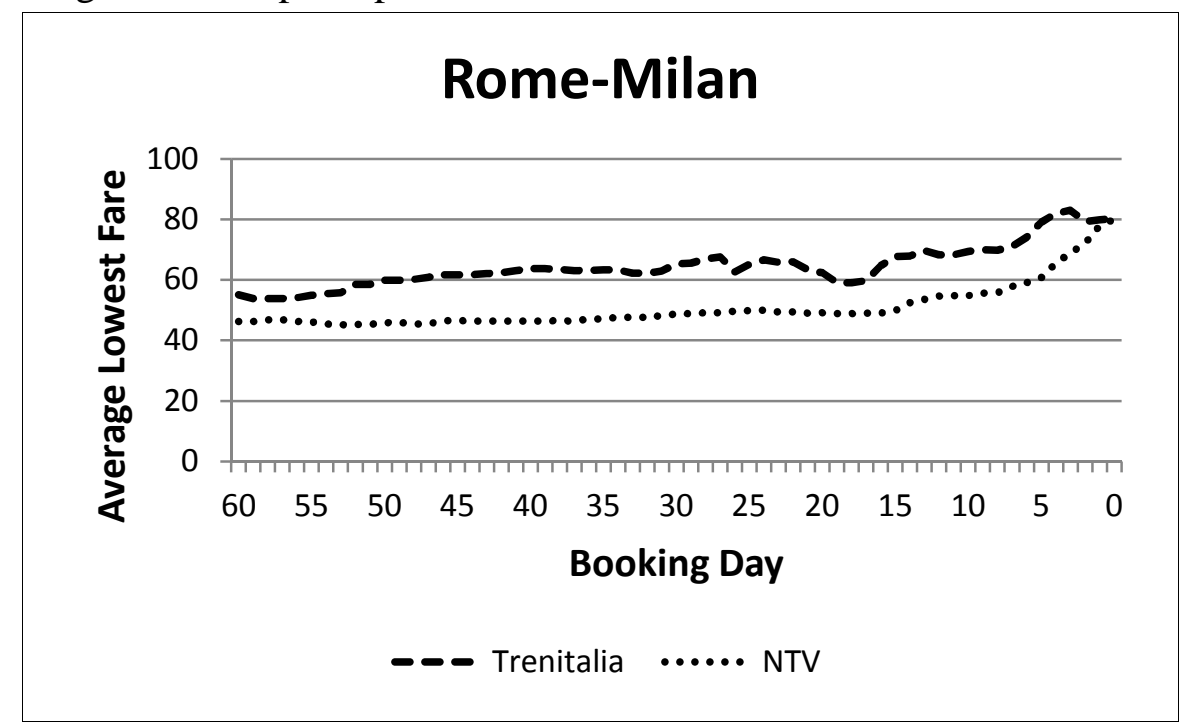

Source: Authors' elaborations on data from operators' websites.

From a preliminary graphical analysis, the pricing strategies of the two operators seem related. After the first five days in which fares are posted on the website, pricing strategies start to diverge. Thereafter, from the 15 days before departure, both operators gradually increase fares, as usually happens when the departure approaches. Fares then converge at the departure. 
Figure 3. Temporal profile of fares on the Rome-Venice route.

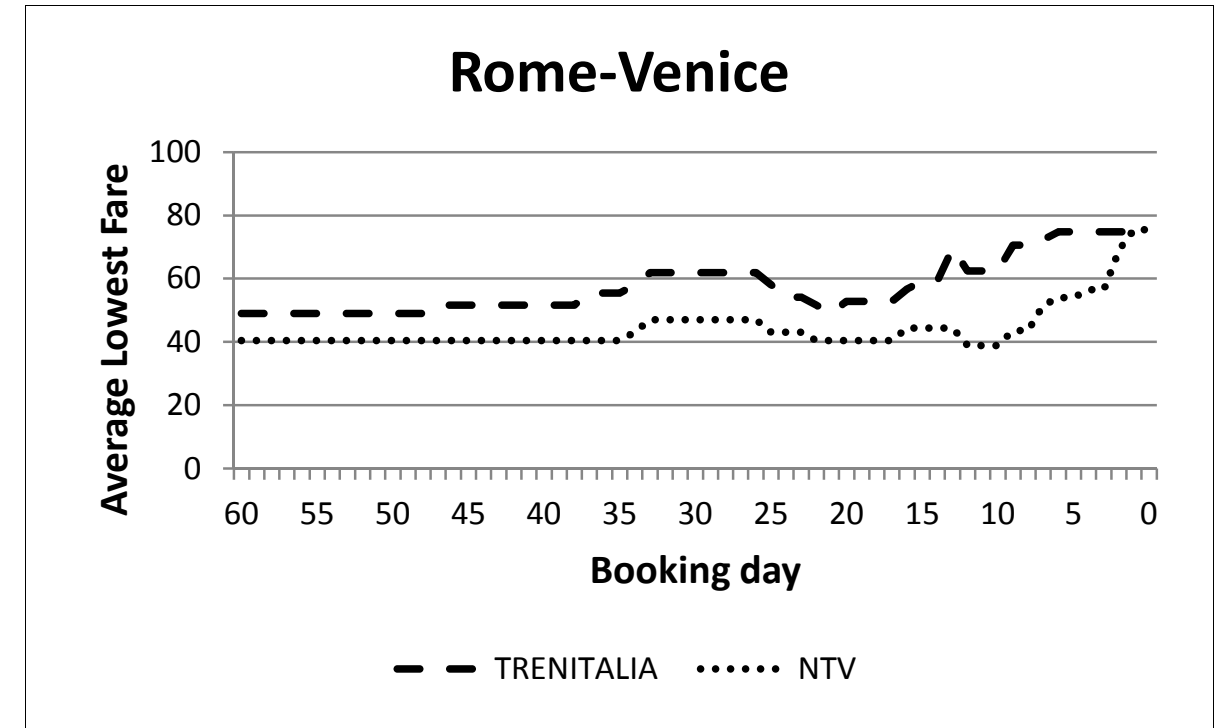

Source: Authors' elaborations on data from operators' websites.

Figure 4. Temporal profile of fares on the Rome-Turin route.

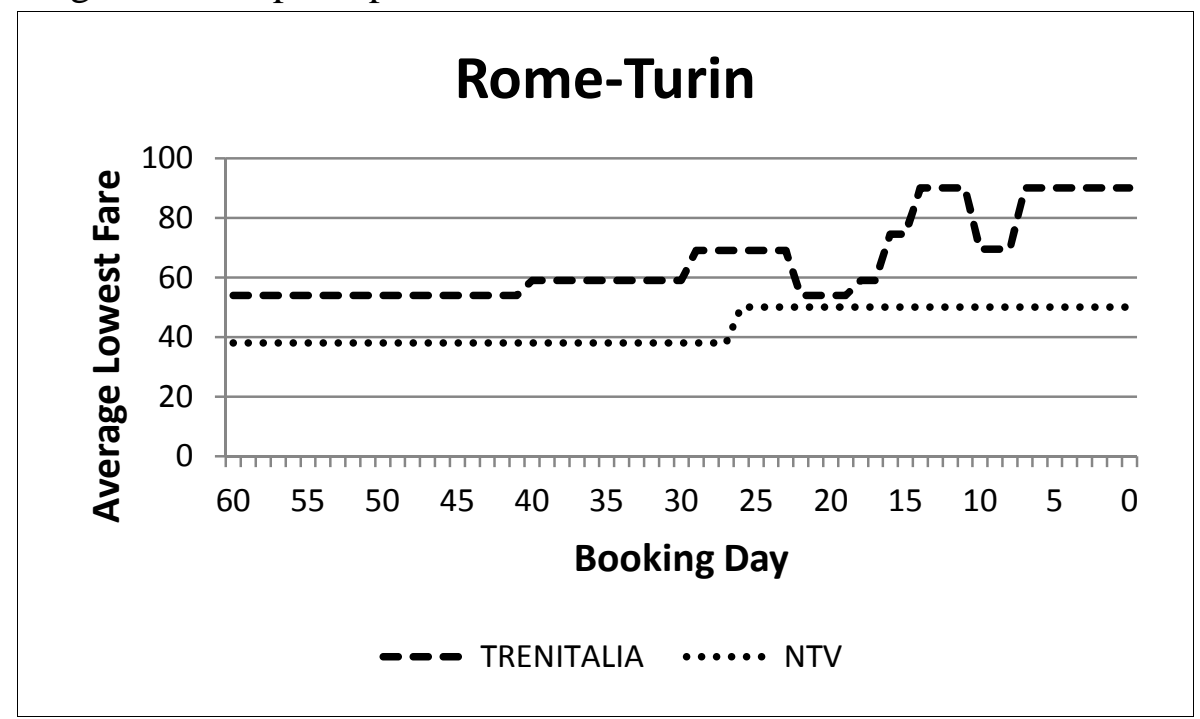

Source: Authors' elaborations on data from operators' websites.

Figures 3 and 4 report the temporal profile of fares for the Rome-Venice and Rome-Turin routes. The pricing behaviours of the two companies seem to be strongly correlated in the last part of the fares' distribution, although the correlation is lower for Rome-Turin line.

To further explore the relationship between fares posted by Trenitalia and NTV, we compute correlations among competitors' average fares to understand whether there is an effective strategic reaction of the newcomer to the incumbent's pricing behaviour or vice versa. We account for different time intervals. 
As shown in Table 5, Rome-Milan is the route that exhibits the highest correlation (87\%) over the 60 days, whereas Rome-Venice shows the lowest correlation (69.2\%).

Table 5. Correlation among Trenitalia and NTV average fares.

\begin{tabular}{lccccc}
\hline \multirow{2}{*}{ Connection } & \multirow{2}{*}{ Full sample } & \multicolumn{5}{c}{ Booking days } \\
& & $60-31$ & $30-0$ & $20-0$ & $15-0$ \\
\hline \hline Rome-Milan & 0.872 & 0.382 & 0.888 & 0.879 & 0.863 \\
Rome-Turin & 0.770 & 0.867 & 0.729 & 0.721 & 0.726 \\
Rome-Venice & 0.692 & 0.131 & 0.233 & 0.715 & 0.740 \\
\hline
\end{tabular}

Correlations might differ depending on the booking day. As long as departure approaches, competitors could more likely take account of rival's pricing behaviour. This seems to occur on the connections for Rome-Milan and Rome-Venice, where the correlation between Trenitalia and NTV fares increases when the departure date approaches.

For the Rome-Milan route, the correlation indices vary between $38.2 \%$ in the interval of the $60^{\text {th }}$ to the $31^{\text {st }}$ day before departure up to $86.3 \%$ in the last fifteen days to departure $(+58.1 \%)$. For the Rome-Venice route, the correlation indices are weaker and vary between $13.1 \%$ in the interval of the $60^{\text {th }}$ to the $31^{\text {th }}$ day before departure up to $74.0 \%$ in the last fifteen days to departure $(+61 \%)$. Differently, on the Rome-Turin route, Trenitalia and NTV adopt a pricing behaviour that diverges along with the days of departure. The correlation reduces from $86.7 \%$ to $72.6 \%(-14.1 \%)$ as departure approaches.

Moreover, we aim at understanding whether Trenitalia and NTV also take into account the fares charged by the competitor in the previous period. Therefore, we compute the correlations among lagged fares. In the left-hand side of Table 6, we report correlations of the NTV average fares at time $t$ with Trenitalia's average fares, considering three time lags (t-1, t-3, t-5). In the right-hand side of Table 6, we show correlations of Trenitalia's average fares at time $t$ with NTV average fares, considering the same time lags. 
Table 6. Correlation between Trenitalia and NTV average lagged fares.

\begin{tabular}{|c|c|c|c|c|c|c|c|c|c|}
\hline \multirow[t]{2}{*}{ Route } & \multicolumn{4}{|c|}{ Trenitalia } & & & \multicolumn{3}{|c|}{$N T V$} \\
\hline & & $t-1$ & $t-3$ & $t-5$ & & & $t-1$ & $t-3$ & $t-5$ \\
\hline Rome - Milan & & $t 0.883$ & 0.884 & 0.787 & & $t$ & 0.861 & 0.859 & 0.863 \\
\hline Rome - Venice & NTV & $t \quad 0.774$ & 0.793 & 0.781 & Trenitalia & $t$ & 0.727 & 0.616 & 0.375 \\
\hline Rome - Turin & & $t 0.692$ & 0.698 & 0.659 & & $t$ & 0.682 & 0.664 & 0.690 \\
\hline
\end{tabular}

Correlations with the lagged fares of the rival suggest that $N T V$ does take into account previous Trenitalia fares, particularly on the Rome-Milan route. The fares set by NTV at time $t$ are highly correlated $(88.3 \%)$ with the fares set by Trenitalia at time $t-1$. There is a high correlation also on the Rome-Venice route (NTV's fares at time $t$ are correlated at $77.4 \%$ with Trenitalia's fares at $t-1)$ and the Rome-Turin route (NTV's fares at time $t$ are correlated at $69.2 \%$ with Trenitalia's fares at $t-1)$. Even Trenitalia's fares show a high degree of correlation with $N T V$ fares, considering the three different lags, mostly on the Rome-Milan route (up to $86 \%$ ).

Summing up, the analysis suggests that Trenitalia and NTV adopt a strategic pricing behaviour in response to the rival's behaviour, which differs across routes. However, the analysis does not allow to state which one is the price leader.

\section{The analysis of inter-modal competition}

While the empirical literature on airline competition and pricing behaviour is quite wide, there is a lack of studies that explicitly focus on the price effect of inter-modal competition. In this paper we test and quantify the effect of the presence of HSR services on fares posted online for the relevant routes on comparative terms with respect to other factors.

\subsection{Empirical strategy}

We define the following equation to measure the effect of HSR presence on airline pricing behaviour: 


$$
\begin{aligned}
\operatorname{Ln}\left(P_{i j k s t}\right)= & \beta_{0}+\beta_{1} \text { Market Share }_{i j k s}+\beta_{2} \text { Intermodal Competition }_{k s} \\
& +\beta_{3} \text { Booking Day }_{t}+\beta_{4} \text { Booking Day }_{t}^{2}+\beta_{5} \text { Off Peak }_{s} \\
& +\beta_{6} \text { Control Dummies }_{i j k s}+u_{i j k s t}
\end{aligned}
$$

where $i$ indexes the route, $j$ the carrier, $k$ the travel date, and $s$ the time slot. The time $t$ is set daily, i.e., $t$ is the day in which a given fare is observed before departure time (it goes from 1 to 60).

The dependent variable is the log of the lowest fares across travel classes set by a given carrier $j$ on a specific route $i$ for the date $k$ in the time slot $s$ at the time $t$.

The variable Market Share is the average share of the number of daily flights operated by an airline for a city-pair. It accounts for the degree of market power and it is expected to have a positive sign because a higher market power allows the airlines to increase fares. We assume that in the very short run, the market share is exogenous. Actually, as Stavins (2001) maintains, in the short run, there are high barriers that hinder entry into a city-pair market. Moreover, this hypothesis is supported by the "grandfather's rights" in the European Union, which guarantee to an airline, holding and using a slot in the previous year, to retain the right to use that slot the next year in the same season. Finally, Bergantino and Capozza (2015) empirically show the exogeneity of airline market share in the short run by implementing the econometric methodology developed by Boreinstein (1989).

The variable Inter-modal Competition is a dummy taking value 1 if a given flight is in direct competition with HSR services in a given time slot, 0 otherwise. We expect this variable to have a negative coefficient, as HSR services, being substitutes of flights on this specific route, should exert a downward pressure on airfares.

We include in the equation the following explanatory variables to control for other factors we know from theory and from previous empirical analysis that might influence airline fares. The variable 
Booking Day measures the effect of inter-temporal price discrimination (IPD) on fares, ${ }^{27}$ it ranges from 1 to 60. We add to the equation the square of Booking Day to control for the non-monotonicity of Booking Day. ${ }^{28}$

Off Peak is a dummy variable that takes value 1 if a given flight takes off during late morning and early afternoon, 0 otherwise. We expect a negative sign because these flights are more likely to be purchased by leisure travellers rather than business travellers, mainly flying in the early morning and evening.

We introduce a set of Control dummies to avoid model misspecification:

- Route dummies that capture the effect of all factors that vary at route level and lead to demand and cost differences, i.e., point-to point distance, hub status, income level and population at the endpoints, etc.;

- Carrier dummies that account for differences in fares among carriers due to the implementation of different pricing techniques; and

- Month dummies that control for further differences during the periods prior to the departure that might be characterised by a greater or a lower demand for travel.

Finally, $u_{i j k s t}=\alpha_{i j k s}+\varepsilon_{i j k s t}$ is the composite error term, where $\alpha_{i j k s}$ is the unobserved heterogeneity and $\varepsilon_{i j k s t}$ is the idiosyncratic error term. Standard errors are clustered at route-level to account for the potential correlation of fares over time and within the same route.

We use the Random Effects (RE) Generalised Least Square (GLS) estimator for the purpose of estimating coefficients of time-invariant variables. To check the consistency of the estimator, we carry out the robust Hausman, developed by Wooldridge, ${ }^{29}$ testing the assumption that explanatory variables are orthogonal to the unobserved heterogeneity.

\footnotetext{
${ }^{27}$ See Stockey (1979), who derives the theoretical setting of IPD, and Gaggero and Piga $(2010,2011)$ who provide the empirical analyses of IPD in the airline industry.

${ }^{28}$ See Bergantino and Capozza (2015)

${ }^{29}$ See Wooldridge (2002), pp. 290-91.
} 


\subsection{Results}

In Table 7, we report the regressions' results. Estimated coefficients seem to support our initial hypothesis on the effect of intra- and inter-modal competition on airline fares.

Table 7. Regressions results.

\begin{tabular}{lcc}
\hline Variables & $\begin{array}{c}\text { Rome (FCO) } \\
\text { Milan (LIN) }\end{array}$ & $\begin{array}{c}\text { Rome (FCO) } \\
\text { Milan (MXP) }\end{array}$ \\
\hline \multirow{2}{*}{ Market Share } & $0.004^{* *}$ & $0.037^{* * *}$ \\
Inter-modal Competition & $(0.002)$ & $(0.003)$ \\
& $-0.155^{* *}$ & $-0.290^{* * *}$ \\
Booking Day & $(0.079)$ & $(0.028)$ \\
& $-0.046^{* * *}$ & $-0.045^{* * *}$ \\
Booking Day & $(0.005)$ & $(0.004)$ \\
& $0.001^{2 * * *}$ & $0.001^{* * *}$ \\
Off Peak & $(0.000)$ & $(0.000)$ \\
& -0.072 & 0.071 \\
& $(0.166)$ & $(0.047)$ \\
Robust Hausman Test & & 1.511 \\
p-value & 1.137 & 0.219 \\
Observations & 0.286 & 1,098 \\
\hline
\end{tabular}

Cluster-robust standard errors at route-level in parentheses.

Control dummies are always included but not reported.

$* * * \mathrm{p}<0.01, * * \mathrm{p}<0.05, * \mathrm{p}<0.10$

Market Share has a positive and highly significant impact on fares. Holding constant other variables, a $10 \%$ increase in the market share leads to $4 \%$ higher fares on the Rome Fiumicino Milan Linate route and return, and to $37 \%$ higher fares on Rome Fiumicino - Milan Malpensa route and return. We need to contextualize the percentage impact with the average fare on each route. The average fare on the Rome Fiumicino - Milan Linate route is about 2.5 times the average fare on the Rome Fiumicino - Milan Malpensa route ( $€ 85.59$ versus $€ 34.61)$. Given the different average fare values and the estimated coefficients, a $10 \%$ increase on the market share leads to an increase of $€ 34.23$ on the Rome Fiumicino - Milan Linate route and return, and an increase of $€ 9.90$ on the Rome Fiumicino - Milan Malpensa route and return. 
The variable Inter-modal Competition has always had a negative and highly significant coefficient. When flights compete with HSR services, airlines are found to price $15.5 \%$ lower on the Rome Fiumicino - Milan Linate route and return, and 29\% lower on the connection Rome Fiumicino Milan Malpensa route and return. The inter-modal competition from HSR services leads to an average savings for consumers of $€ 13.26$ on the Rome Fiumicino - Milan Linate route, and of $€ 9.90$ on the Rome Fiumicino - Milan Malpensa route. Therefore, the empirical evidence is in favour of the effectiveness of inter-modal competition in exerting a downward pressure on airline fares.

The relationship between Booking Day and fares is non-monotonic. The coefficient of Booking Day is negative and significant, whereas the coefficient of Booking Day squared is positive and highly significant. This means that Booking Day has a negative effect on fares until the turning point is reached. From the analysis we estimate the turning point at the $23^{\text {th }}$ day before departure. Beyond that day, fares begin to increase as departure date approaches.

Finally, the variable Off Peak is not significant, which might be quite surprising. However, the absence of a significant price difference among time slots should be driven by the high demand on the Rome-Milan city pair market, which is very crowded at each time of the day such that airlines do not need to apply a peak-load pricing technique to shift the demand towards less crowded hours. The results of the robust Hausman Test do not lead us to reject the null hypothesis that RE GLS estimator is consistent.

\section{Concluding comments}

We study the competitive effects of HSR entry in the Italian passenger market. Despite the relevance of regulatory and policy implications of this issue, the research on the competing HSR services is very scanty.

In this paper we deal with two issues. First, we explore the price and capacity effects of intra-modal competition between HSR operators. Second, we measure the effect of inter-modal competition by 
HSR on airline pricing behaviour. The analysis is carried out on the Italian market because this is the first and most extensive case where two railway companies compete on an open access basis.

The results suggest that the incumbent Trenitalia has not reduced its supply as a result of NTV entry. Actually, the data on daily frequencies highlight that Trenitalia increased the capacity deployed on the lines by $30 \%$ from the year previous to NTV entry. The presence of the newcomer has lead to an increase of the overall capacity on the Rome-Milan city-pair by $56 \%$. The on-track competition has resulted in a greater utilization of the network. The provision costs of HSR services and the amount of public investments in new or upgraded lines should be evaluated in light of the benefits for the community, which appear to be rather important.

However, we do not find evidence of predatory pricing by the incumbent. In fact, Trenitalia's fares are $29.92 \%$ to $34.67 \%$ higher than $N T V$ 's. Instead, we find that the two railway companies do engage in strategic pricing, although to a different degree on different routes. Both rail companies take into account the dynamics of the rival's pricing behaviour, although $N T V$ seems to do so more carefully than Trenitalia when setting the tariffs over time.

It took about two years for NTV to begin its operations, as it encountered various difficulties in obtaining the slots and the authorizations. Still, there is discrimination with respect to the spaces allocated to $N T V$ within the railway stations. This underlines the importance of the regulator independence from the infrastructure owner and also from the incumbent railway undertaking.

The results on the inter-modal competition show the effectiveness of railway services in moderating the level of fares charged by airlines. After controlling for IPD, airline market share and other flight characteristics, we estimate that the presence of inter-modal competition on the Rome-Milan citypair market reduces airline fares up to 13.26 Euros.

This finding sheds a new light on the effects of HSR competition, having not only a direct effect on rail services (frequency and fares), but also a significant impact on the airline market. On a route where airline competition is quite limited - due, for instance, to the antitrust exemption granted to Alitalia when it merged with Airone - the presence of HSR services is a valuable tool for controlling 
airfares. Competition among rail operators has, thus, also indirectly benefitted those consumers who are captive to air services.

In defining policy interventions in the railway market, more attention should be posed to these indirect benefits of inter-modal competition. Currently, HSR infrastructure is mostly developed in the north-centre of Italy, whose consumers significantly benefit from HSR transport services, both directly (intra-modal competition) and indirectly (inter-modal competition). The indirect effects would be even more important for the citizen living in the south of Italy, where the HSR network is rather less developed. Besides the effect of moderating airfares, HSR services would enhance the accessibility with positive spillovers on the Italian regions. The cost of providing HSR services should also be compared with the indirect benefits, leading to savings for travellers, thanks to the competitive pressures on the airline markets. Obviously, should Alitalia be again the object of public intervention, the beneficial effect of competition should be balanced out against the public subsidies that are allocated to Alitalia to cover losses.

\section{Acknowledgements}

We wish to thank participants to the European Railway Agency (ERA) workshop held in Lille in September 2013, in particular Chris Nash and John Preston for very useful insights. We are especially indebted to Torben Holvad and Ernest Godward for the useful discussions during the internship period Mauro Capurso spent at the Agency. The authors would also like to thank reviewers and participants to the 13th WCTR in Rio de Janeiro for comments and suggestions on a previous draft. All remaining errors are ours. 


\section{References}

Alderighi, M. and Bergantino, A.S. (2011) "Servizi minimi e cream-skimming nel settore ferroviario: una nota”, in Borruso G., Danielis R. and E. Musso (eds) Trasporti, Logistica e reti di imprese. Competitività del sistema e ricadute sul territorio, FrancoAngeli, Milano.

Alderighi, M. and Bergantino, A.S. (2013) "The competitive effects of entry in the railway sector with partial regulation", Mimeo.

Antes, J., Friebel, G., Niffka, M. and Rompf, D. (2004) "Entry of low-cost airlines in Germany: some lessons for the economics of railroads and inter-modal competition", proceedings from the Second conference on Railroad Industry Structure, Competition and Investment, Northwestern University, Evanston, IL.

Autorità Garante per la Concorrenza ed il Mercato (2013) "Antitrust avvia istruttoria per verificare se il gruppo FS abbia abusato della propria posizione dominante per favorire Trenitalia ostacolando NTV. Procedimento deliberato alla luce delle segnalazioni ricevute dal concorrente", Reference Number A443, Rome, May 28, 2013 http://www.agcm.it/component/joomdoc/doc_download/3705-a443avvomi.html

Autorità Nazionale per i Trasporti (2014) “Documento di consultazione nell'ambito del procedimento sul tema dell'accesso equo e non discriminatorio alle infrastrutture ferroviarie", http://www.autorita-trasporti.it/accesso-infrastrutture-ferroviarie/.

Behrens, C. and Pels, E. (2012) "Inter-modal Competition in The London-Paris Passenger Market: High-Speed Rail and Air Transport”, Journal of Urban Economics, 71(3), pp. 278-288.

Bergantino, A.S. (2006) "Lo sviluppo dei vettori low cost: nuovi assetti organizzativi e ampliamento della clientela", in Macchiati, A. and Piacentino, D. (eds), Mercati e politiche pubbliche nell'industria del trasporto aereo, il Mulino, Bologna.

Bergantino, A.S. (2015) "Incumbents and new entrants" in Finger, M. and Jaag, C. (eds.) The Routledge companion to network industries, Routledge, London. 
Bergantino, A.S. and Capozza, C. (2014) "One price for all? The role of market captivity as price discrimination device. Evidence from the Italian city-pair markets." SIET Working paper.

Bergantino, A.S. and Capozza, C. (2015) "Airline Pricing Behavior under Limited Inter-modal Competition”, Economic Inquiry, 53(1), pp. 700-713.

Bergantino, A.S. and Ponti M. (2006) "Le compagnie low-cost e la tutela dei consumatori”, Consumatori, Diritti e Mercato, 1, pp. 57-74.

Betancor, O. and Jiménez, J.L. (2012) "When trains go faster than planes: The strategic reaction of airlines in Spain", Transport Policy, 23, pp. 34-41.

Borenstein, S. (1989) "Hubs and High Fares: Dominance and Market Power in the U.S. Airline Industry", The RAND Journal of Economics, 20(3), pp. 344-365.

Campos, J. and de Rus, G. (2009) "Some stylized facts about high-speed rail: A review of HSR experiences around the world", Transport Policy, 16(1), pp. 19-28.

Cao, J. Liu, X.C., Wang, Y. and Li, Q. (2013) “Accessibility impacts of China's high-speed rail network", Journal of Transport Geography, 28, pp. 12-21.

Competition, Integration, Substitution: Myths and realities concerning the relationship between high-speed rail and air transport in Europe Gaggero, A.A. and Piga, C.A. (2010) "Airline competition in the British Isles", Transportation Research Part E, 46(2), pp. 270-279.

Directorate-General for Mobility and Trasport, European Commission, Statistical Pocketbook 2013, http://ec.europa.eu/transport/facts-fundings/statistics/pocketbook-2013_en.htm.

Dobruszkes, F. (2011) "High-speed rail and air transport competition in Western Europe: A supplyoriented perspective", Transport Policy, 18(6), pp. 870-879.

Dobruszkes, F. and Givoni, M. (2013) "Competition, Integration, Substitution: Myths and realities concerning the relationship between high-speed rail and air transport in Europe", in Budd, L., Griggs, S., Howarth, D. (eds.) Sustainable Aviation Futures, Emerald Group Publishing Limited, Bingley, UK. 
Eurostat (2011) "Air passenger transport between the main airports of Italia and their main partner airports (routes data)", Eurostat $\quad$ Statistics http://appsso.eurostat.ec.europa.eu/nui/show.do?dataset=avia_par_it\&lang=en

Fageda, X., Jiménez, J.L. and Perdiguero, J. (2011) "Price rivalry in airline markets: a study of a successful strategy of a network carrier against a low-cost carrier", Journal of Transport Geography, 19(4), pp. 658-669.

Gaggero, A.A. and Piga, C.A. (2011) “Airline Market Power and Intertemporal Price Dispersion”, Journal of Industrial Economics, 59(4), pp. 552-577.

Givoni, M. and Banister, D. (2006) “Airline and railway integration”, Transport Policy, 13(5), pp. 386-397.

Gonzalez-Savignat, M. (2004) "Competition in air transport: the case of the high speed train", Journal of Transport Economics and Policy, 38(1), pp. 77-108.

Gutiérrez, J. (2001) "Location, economic potential and daily accessibility: an analysis of the accessibility impact of the high-speed line Madrid-Barcelona-French border", Journal of Transport Geography, 9(4), pp. 229-242.

Gutiérrez, J., González, R. and Gómez, G. (1996) “The European high-speed train network: Predicted effects on accessibility patterns", Journal of Transport Geography, 4(4), pp. 227-238.

Holvad, T. and Godward, E. (2013) "Railway Regulation in Europe: status and future perspectives", proceedings from the $2^{\text {nd }}$ Conference on the Regulation of Infrastructure Industries, Florence.

Holvad, T., Godward, E. and Capurso, M. (2013) “The reform of Europe's passenger railways: the need for interoperabilità", proceedings from the $13^{\text {th }}$ Thredbo International Conference Series on Competition and Ownership in Land Passenger Transport, Oxford.

Ivaldi, M. and Vibes, C. (2005) "Inter-modal and Intra-modal competition in Passenger Rail Transport", CEPR Discussion Paper No. 5004. 
Janic, M. (1993) "A model of competition between high speed rail and air transport", Transportation Planning and Technology, 17 (1), pp. 1-23.

Kappes, J.W. and Merkert, R. "Barriers to entry into European aviation markets revisited: A review and analysis of managerial perceptions", Transportation Research Part E: Logistics and Transportation Review, 57, pp. 58-69.

Longobardi, T. (2013) “I benefici effetti della concorrenza ferroviaria”, I mille, January 2.

Martin, J.C. and Nombela, G. (2007) "Microeconomic impacts of investments in high speed trains in Spain”, The Annals of Regional Science, 41(3), pp. 715-733.

Merkert, R. (2012) “An empirical study on the transaction sector within rail firms", Transpormetrica, 8(1), pp. 1-16.

Ministero delle Infrastrutture e dei Trasporti (2013) Conto Nazionale delle Infrastrutture e dei Trasporti, Zecca dello Stato, Roma.

Nuovo Trasporto Viaggiatori (2013) Da zero a Italo. Così è nata la concorrenza, Skira, GinevraMilano.

Ponti M. and Beria P. (2009) "Liberalisation and regulation of railways. European experiences and possible strategies for Italy", proceedings from the SIG4 - TER Italia Conference, organized by the Research Center for Transport Policy, Milan, Nov. 16th 2009.

Ponti M. and Erba S. (2002) "Railway Liberalization from a "Public Choice" Perspective", European Transport, 20-21, pp. 36-44.

Preston, J. (2012) “High Speed Rail in Britain: about time or a waste of time?", Journal of Transport Geography, 22, pp. 308-311.

Román, C., Espino, R. and Martin, J.C. (2007) “Competition of high-speed train with air transport: the case of Madrid-Barcelona", Journal of Air Transport Management, 13(5), pp. 277-284.

Román, C., Espino, R. and Martin, J.C. (2010) "Analyzing competition between the high speed train and alternative modes: The case of the Madrid-Zaragoza-Barcelona corridor", Journal of Choice Modelling 3(1), pp. 84-108. 
Stavins, J. (2001) "Price Discrimination in the Airline Market: The Effect of Market Concentration", The Review of Economics and Statistics, 83(1), pp. 200-202.

Steer Davies Gleave. Air and Rail Competition and Complementarity, Luxembourg: Office for Official Publications of the European Communities, 2006.

Stokey, N. (1979) “Intertemporal price discrimination”, Quarterly Journal of Economics, 93(3), pp. 355-371.

Trenitalia (2012) "Bilancio di esercizio" http://www.fsitaliane.it/cmsfile/allegati/fsitaliane/Bilancio_12_Trenitalia_web.pdf

Union Internationale de Chemin de Fer (2010). High-speed and the city, Paris.

Willigers, J. and van Wee, B. (2011) "High-speed rail and office location choices. A stated choice experiment for the Netherlands", Journal of Transport Geography, 19(4), pp. 745-754.

Wooldridge, J. M. (2002) Econometric Analysis of Cross Section and Panel Data, The MIT Press, Cambridge, MA.

Yang, H. and Zhang, A. (2012) "Effects of high-speed rail and air transport competition on prices, profits and welfare", Transportation Research Part B, 46 (10), pp. 1322-1333. 